\title{
COMMENTARY
}

\section{Eating inequity: The injustice that brings us our food}

\author{
Manar Arica Alattar* \\ University of Portland and Portland Community College
}

Submitted January 2, 2021 / Published online June 23, 2021

Citation: Alattar, M. A. (2021). Eating inequity: The injustice that brings us our food. Journal of Agriculture, Food Systems, and Community Development, 10(3), 17-30. https://doi.org/10.5304/jafscd.2021.103.003

Copyright (C) 2021 by the Author. Published by the Lyson Center for Civic Agriculture and Food Systems. Open access under CC-BY license.

\begin{abstract}
As we eat, we transform social, natural, and economic systems. Here we briefly explore these transformations.

\section{Keywords}

Food System, Food Justice, Food Workers, Farmworkers, Climate Change, Food Waste, Wasted Food, Greenhouse Gas

\section{Introduction}

Climate change and global warming have become common phrases in politics, at schools, and at dinner tables. We, largely, understand that human impact on the environment is changing our world in both predictable and unpredictable ways. Species are being lost at an alarming rate (Feldstein, 2017); weather patterns are being disrupted and becoming more extreme (Neff, 2014); pests and invasive species are wreaking havoc (Schapiro, 2018); the Amazon is in flames (McCoy, 2019); and plastics are choking out our aquatic ecosystems (Derraik, 2002). What ties a majority of these global problems together? Con-
\end{abstract}

\footnotetext{
** Manar Arica Alattar, Ph.D., Food Systems and Biology Lecturer, Department of Environmental Studies, University of Portland; 5000 North Willamette Boulevard; Portland, OR 97203 USA; and Department of Biology, Health Technology (HT), Portland Community College; Room 305, 12000 SW 49th Avenue; Portland OR 97219 USA; manaraalattar@gmail.com

Funding Disclosure

This work was supported in part by funding through Salem Press to promote scientific work that is accessible for an undergraduate audience.
} 
sumption patterns often related to food. Food is a strong cultural, personal, and political driver (Brown, 2012; Mbow et al., 2019). Food is, arguably, the primary resource for which we alter our environment: land, water, and air. In the last 300 years, food production has led to the loss of $20 \%$ of grasslands and forests worldwide and 30\% of North American forests (U.S. Department of Agriculture [USDA], 2014). Seventy percent of global freshwater is used for producing food (Food and Agriculture Organization of the United Nations [FAO], 2017). A third or more of global human greenhouse gas (GHG) emissions come from food production (Foer, 2019; Intergovernmental Panel on Climate Change [IPCC], 2013). So, let's talk about food.

Think about this for a moment: your food (in the U.S.) travels an average of 15 hundred miles $(24,140 \mathrm{~km})$ before it reaches you, and sometimes much more (Henne, 2012). Your food may have even traveled to various other continents and back before you eat it. The food you eat, in a few days or weeks, may have traveled more than you have in your lifetime.

The food that we eat is no longer produced primarily by farmers. Farmers are just a peg in the vast, global, and interconnected web of production, processing, distribution, and sales. Shopping at your local supermarket is actually a global experience. Without even thinking about it, we regularly eat avocados from Mexico, coffee from Ethiopia, bananas from Ecuador, shrimp from Malaysia, and fish raised in the U.S., processed in Asia, and then shipped back to the U.S. for sale. In considering this global food system, we must understand and address some very important questions. Who brings us our food, and are they treated justly? How is our food shaping natural environments as it is produced and transported to us? What can we do about it all?

Considering our "foodprint" in this way is essential because (1) "you are what you eat," and (2) it tells us a chilling story that is more relevant to social and climatic health than whether or not you bicycle to work. So, let's address these questions in turn.

\section{Who brings us our food, and are they treated justly?}

As your food travels thousands of miles through a complex national food web with almost 10 million links (Lin et al., 2019), numerous people work to pass it along its journey, from farmers to farmhands, processing-plant workers, truck drivers, barge captains, grocery-store employees, cooks, servers, and more. In the U.S., 21.5 million people (14\% of the population) work in the food supply chain (Food Chain Workers Alliance \& Solidarity Research Cooperative, 2016). These workers earn a median wage of US $\$ 10 /$ hour, which is significantly lower than the median wage across industries (US $\$ 16 /$ hour). Additionally, these workers work in some of the most hazardous jobs, report significant levels of sexual harassment (especially farm and restaurant workers), and are nearly twice as likely to use food stamps compared to the general population (Food Chain Workers Alliance \& Solidarity Research Cooperative, 2016; Jayaraman, 2016; Yeung, 2018). Foodservice workers report little opportunity for promotion within their fields and consistently have among the highest turnover rates nationwide (Compensation Force, 2017; Food Chain Workers Alliance \& Solidarity Research Cooperative, 2016). Farmhands, a majority of whom are Latino, also face harsh working conditions, pesticide exposure, wage theft, and various other injustices, particularly when undocumented (Edelson, Monani, \& Platt, 2018; Hernandez \& Gabbard, 2018; Marquis, 2017). In fact, service and farmworkers are exempt from pivotal national policy protecting worker rights to unionize and earn a fair wage (Perea, 2010).

Furthermore, discriminative lending, redlining, and other practices that inhibit landownership have impeded racial minorities, specifically Black Americans, from owning land and farming (Penniman, 2018). Today only $1.3 \%$ of American farmers are Black, and they only own $0.52 \%$ of American farmland (while the Census reports that $13.4 \%$ of Americans identify as Black Americans) (Sewell, 2019). This is a significant decrease from the 1920s, when $14 \%$ of American farmers were Black (Newkirk, 2019). 
In fact, race and gender disparities are pervasive throughout food work. Racial minorities face significant hiring discrimination (Jayaraman, 2016), and even after they are hired, minorities earn 44 to 80 cents to the dollar of white workers (Food Chain Workers Alliance \& Solidarity Research Cooperative, 2016). This is not surprising from a national food system historically based on slave labor and the confiscation of Native lands (Newkirk, 2019; Penniman, 2017, 2018). Even though almost 40\% of food workers identify as people of color and almost $35 \%$ of food workers are women, $72 \%$ of food industry CEOs are white men, and $14 \%$ are white women (Food Chain Workers Alliance \& Solidarity Research Cooperative, 2016). Women working in the food supply chain earn less than half of their male counterparts and have historically been undercompensated for vast amounts of care work, including that related to food production and preparation (Food Chain Workers Alliance \& Solidarity Research Cooperative, 2016; Patel \& Moore, 2017). Such trends are reflected across the world as well. Globally, 65\% of working poor adults are employed in the food system (Townsend, Benfica, Prasann, \& Lee, 2017). Many of these workers produce food for sale abroad and find it difficult to meet the needs of their own households (Patel, 2012).

Farmhands and service workers are not the only victims of the food system. Fewer family farmers can survive corporate food competition and buy-outs, even though the large corporate farms that take their place do scores of damage to environmental and social systems (Carlisle, 2016; Gustafson, 2014). Between 1950 and 2012, the number of farms in the U.S. decreased by 40\% and the average size increased by $75 \%$ as small and midsized farms were lost (Imhoff \& Badaracco, 2019). Today, the largest $8 \%$ of farm operations in the U.S. supply $80 \%$ of food sales (Neff, 2014). A majority of the remaining small farms rely on additional nonfarming incomes for financial stability, and less than half even make a net profit from farming (Figure 1) (Higgins, 2019). American farmers receive 7.6 cents in each dollar of sales from their raw products, a record low in the last 15 years (USDA, 2017). Corporate interests and sales, on the other hand, receive 85.4 cents of each food dollar (USDA, 2017). Across the nation, farmers are aging; almost a third are over 65 years of age, and only 8 percent are under 35 (Neff, 2014). There is a deficit in both beginning and young farmers to take over farming, as barriers to entry are significant and income instability tends to be high throughout a farming career (Imhoff \& Badaracco, 2019; Niewolny \& Lillard, 2010). Suicide rates among farmers are among the highest of any occupational group in the U.S. and have spiked with recent historical flooding, the international trade war, and the pandemic (Gowen, 2019; Rosmann, 2017; Weingarten, 2018). The recent

\section{Figure 1. Old McDonald is Struggling}

Although family farmers represent the majority of farmers in the U.S., they are increasingly unable to profit from and live off their farms (Klein \& Locke, 2014).

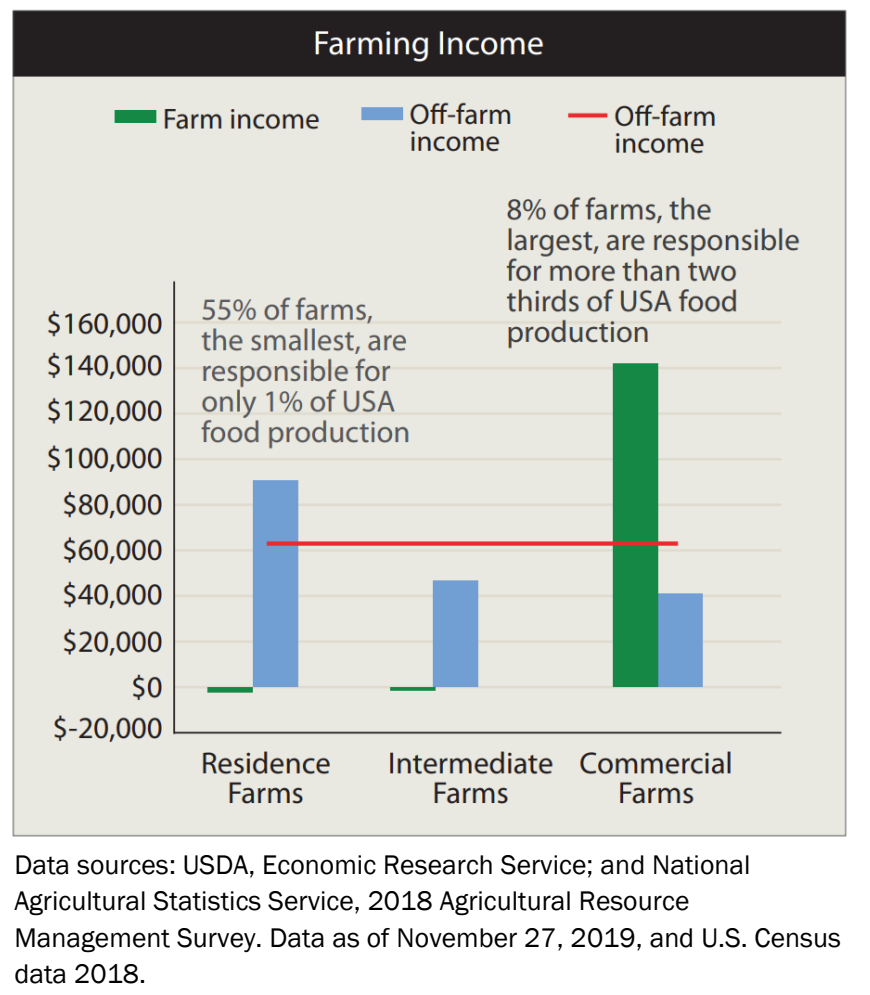


disruptions in food markets and distribution due to the COVID-19 pandemic have mental health professionals bracing for a continued increase in mental health issues in farming communities and beyond (Pappas, 2020; Singh, 2020).

These disparities are perpetuated by national policies that promote massive, monoculture, primarily absentee-owned, commodity crop farms, particularly through the historic "get big or get out" influence of USDA secretary Earl Butz of the 1970s (Gustafson, 2014). Butz focused on improving the quantity and efficiency of commodity crop production. Unfortunately, the resulting policy set the stage for a reliance on large-scale monocrop and concentrated feedlot operations, which cause a great deal of damage to local environments and social structures, as opposed to small and midscale operations producing diverse and nutritious foods (Imhoff \& Badaracco, 2019; Raff \& Meyer, 2019). Fruits and vegetables, for example, were (and still are) only considered "specialty crops" in the farm bill, the nation's primary food and farm legislation (Imhoff \& Badaracco, 2019). Farmers in the early 1900s represented 36\% of the national population, whereas today, they represent under 2\% (Neff, 2014; Pollan, 2015).

Even more extreme consolidation of power occurs among seed companies; over 200 years, we have gone from thousands of local natural seed companies nationally to having primarily four large international chemical and/or pharmaceutical companies dominating the seed industry (MacDonald, 2019; Schapiro, 2018). "Why chemical and pharmaceutical companies?" you may ask. It's because seeds can be engineered to depend on or even produce natural variants of specific chemicals such as pesticides and herbicides (MacDonald, 2019). This improves plant growth in industrial settings but has severely decreased the diversity and resilience of food plants and the availability of local seed varieties (Mbow et al., 2019; Schapiro, 2018). Over time, our food system has evolved such that a smaller and smaller number of larger and larger farms and corporations provide us our food.

Truth be told, you don't have to work with food to eat. Therefore, we are all affected by injustices in the food system. Let's go back to food policy. We, the eaters, have historically received mixed official messages about food. Take, for example, the comparison in Figure 2 between MyPlate nutritional recommendations and actual governmental subsidies of those same food categories (Badaracco, 2019).

The historical rise of junk food from excess production of corn and other commodity crops, along with lifestyle changes, are correlated with a massive health epidemic that is spreading worldwide (Gustafson, 2014). For the first time in history, people who are overweight or obese globally outnumber those who are hungry (Capone et al., 2014). Furthermore, "food" that is calorie-dense but of little nutritional value tends to be cheap, meaning that hunger and

\section{Figure 2. Comparison of MyPlate versus AgSubsidy Plate}

Are national stakeholders on the same page about what food we should be eating? It seems not. Compare the MyPlate nutritional recommendations to the equivalent plate if it were developed based on agricultural subsidies of those same foods.

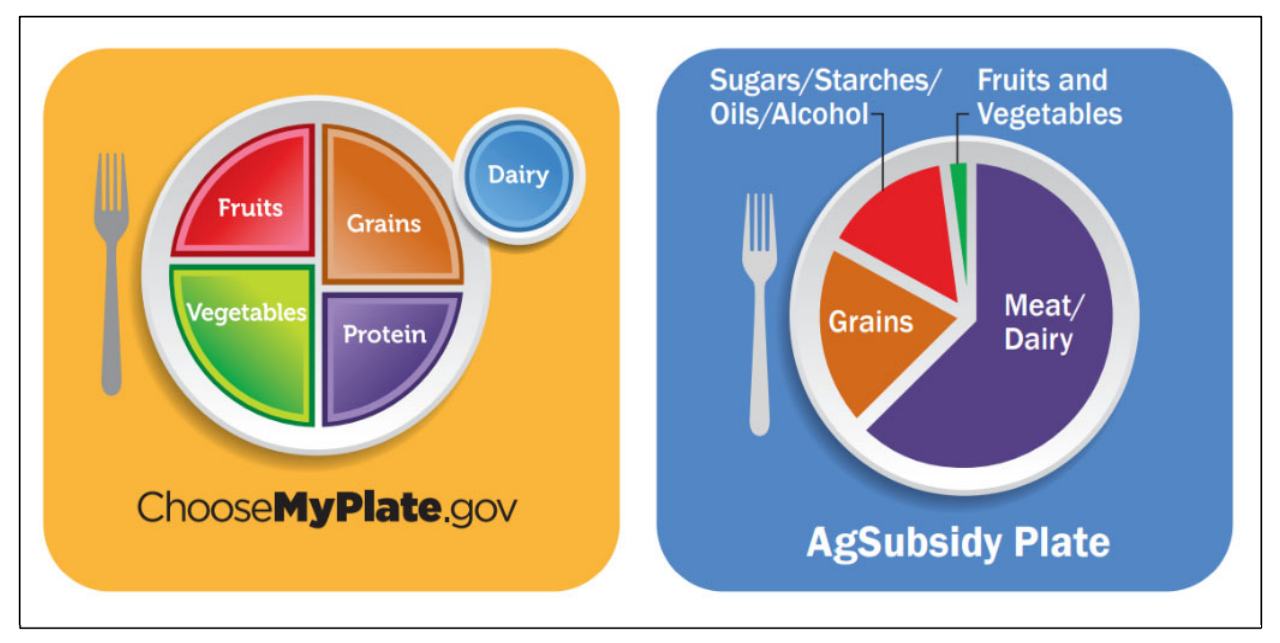

Source: The Edible Schoolyard Project, 2019 (42:39 of the video); new image created by the author and Patti Davis and team. 
overweightness often run parallel in populations that have historically been excluded from access, autonomy, and opportunity for both economic growth and political influence (Fisher, 2017; Northridge et al., 2003).

In an age where many infectious diseases are controlled (of course, COVID-19 has provided an exception), we are instead overrun with food- and lifestyle-related conditions such as obesity, coronary heart disorder, and type 2 diabetes, even in children and particularly in Indigenous, Black American, and other historically disadvantaged communities (Fisher, 2017; D. M. Nestle et al., 2015). The Centers for Disease Control and Prevention (CDC) reports that 39.8\% of Americans are obese, with even higher rates among minorities (CDC, n.d.). The obesity epidemic costs the U.S. an estimated total of US $\$ 1.7$ trillion annually between health care costs (US $\$ 480.7$ billion) and lost productivity (US $\$ 1.24$ trillion) (Milken Institute, 2018; Waters \& Graf, 2018). In response to health woes and negative messaging about body image, individuals often become wrapped up in the massively confusing culture (and US\$60 billion a year industry) of dieting (M. Nestle, 2013). Instead, eating can be as simple as, "Eat food. Not too much. Mostly plants" (Pollan, 2008, p. 1) — that is, if those foods are accessible to a given population.

Overconsumption worldwide exists simultaneously with malnutrition. Globally, 836 million people ( $12 \%$ of the world's population) live in extreme poverty (less than US $\$ 1.25$ a day), and approximately one million children a year die from the effects of starvation (Capone et al., 2014; United Nations [UN], 2015). In 2019, 10\% of Americans (35 million) were food-insecure (defined as individuals who "experience limitations in access to adequate food to the extent that it causes changes in diet or reduced food intake" [Weinfield et al., 2014, p. 132]) (USDA ERS, 2020). Twenty percent of food-insecure Americans are children, and 10\% are elderly (Feeding America, n.d.). Furthermore, food insecurity rates are significantly higher among Black Americans (25\%), Native Americans (23-45\%), and Hispanic Americans (26\%), compared to White Americans (10\%) (Neff, 2014). Disruptions in employment, food distribution, and social systems generally due to the COVID-19 pandemic have led food insecurity rates to spike to over $15 \%$, with the greatest impact being on communities of color and other communities that were already experiencing increased food insecurity before the pandemic (Hake et al., 2020).

Similarly, through historical social, economic, and resource disenfranchisement, these populations often find themselves in communities characterized as food deserts (also called areas of food apartheid), with limited access to grocery stores and fresh produce (Penniman, 2018). Only 8\% of Black Americans, for example, live in a neighborhood with one or more grocery stores, compared to $31 \%$ of White Americans (Penniman, 2017).

Yet, we produce enough food to feed all world citizens twice their daily nutritional needs (about 2,000 calories). In the U.S., almost 4,000 calories of food are available per man, woman, and child (M. Nestle, 2013). Globally, over 5,000 calories of food directly edible by humans are produced per person annually; that figure almost doubles if you include food produced to feed animals (Berners-Lee et al., 2018). Food is available and abundant, but poorly distributed.

It may be becoming clear that food is, in fact, very political (Poska, 2019). Food has historically had implications in power and social activism (Bellemare, 2015). The Arab Spring was preceded by disruptions in food prices (Perez, 2013). Mexican drug cartels are increasingly taking control of forests and farms to benefit from avocado revenues (Linthicum, 2019). Land grabbing, or the acquisition of large swaths of fertile foreign land by governments and corporations without proper compensation to the local stakeholders, has increased dramatically as food and climate change become more pressing (Margulis et al., 2013). The World Bank estimates that 45 million hectares had been acquired through transnational purchases between 2008 and 2012 in all continents, save Antarctica (Rulli et al., 2013).

A plethora of food movements, including those related to social justice, food sovereignty, slow food, organic food, vegetarianism and veganism, and more have utilized food to drive positive social and 
environmental change (Neff, 2014). Racial justice movements of the 1960s, for example, focused on food sovereignty and food justice for Black Americans in communities, schools, and places of work (Penniman, 2018). Food continues to be essential to social justice movements today (Simley, 2017). The COVID-19 pandemic has also brought food to the forefront of personal and political discourses, with strong advocacy (often met with political resistance) to improve food security (Hake et al., 2020), the working conditions and wages of essential food works (Wozniacka, 2020), food system resilience through localization and decentralization (Lal, 2020; Mejia et al., 2020), and much more.

In order for our food to be just, it has to be produced in a system that values the people who produce it and the people who eat it (Rodman-Alvarez \& Colasanti, 2019). This system must value individual and community health over wealth (Gaddis et al., 2020). Just some of the changes that can be made are creating intentional policy to ensure just distribution of and access to healthy food; improving economic opportunity for food chain workers worldwide; instigating legislative reform around worker rights and wages; limiting the power of Big Food, agriculture, pharmaceutical, and chemical companies on markets, food prices, and policy; and restructuring subsidies to support midscale, sustainable, and diverse agriculture.

\section{How is our food shaping natural environments as it is produced and transported to us?}

Imagine flying over a landscape. Maybe you've flown in a plane. Some of the most distinct topographical features you'll see are those related to food production: the characteristic square and circular monocultured fields, the irrigation ponds, and the sparsity of forests where they have historically dominated. Land use and other environmental impacts related to food production change natural ecosystems drastically.

Let's start with water. On our water-covered planet, less than $1 \%$ is accessible freshwater. We use $70 \%$ or more of that water for agricultural and livestock production (FAO, 2017). It takes about 13 liters (3.4 gallons) of water to produce a tomato, 140 liters ( 37 gal.) for a cup of coffee, and a whopping 2,400 liters (634 gal.) to produce a hamburger patty (Hoekstra, 2008; Water Footprint Calculator, 2020). At the same time, 1 in 3 people globally does not have access to safe drinking water (World Health Organization [WHO], 2019). In addition, agriculture and livestock produce overwhelming amounts of pollution that run into surrounding water bodies. Contamination is widespread and has been documented in $80 \%$ of U.S. streams (National Critical Zone Observatory, 2012; Thyberg \& Tonjes, 2016). Nutrient and sediment displacement by agriculture also weakens aquatic systems. Specifically, eutrophication, or excess nutrients causing algal blooms and eventual anoxia in aquatic systems, is the leading cause of waterbody degradation, affecting $65 \%$ of U.S. waterways (National Oceanic and Atmospheric Administration [NOAA], 2019). Eutrophication in the U.S. alone is estimated to cost US\$2.2 billion annually (Chislock et al., 2013).

The significant amount of waste produced from concentrated animal feed operations (CAFO) is of particular concern as well (Imhoff \& Badaracco, 2019). In the U.S., more than 335 million tons of dry manure (laden with chemicals and antibiotics) is produced annually from swine, poultry, and cattle operations; much of that waste is stored in lagoons (USDA, 2004). A single CAFO can produce more lagoon wastewater than a human city, with significantly less regulation around pathogen removal and treatment of said water (Neff, 2014; Raff \& Meyer, 2019).

Oceans are also suffering. Historic overfishing and pollution have led to fisheries crashing, coral reefs being bleached, and habitats being destroyed (Li et al., 2016; Springmann et al., 2018). Plastic may soon outnumber plankton as 8 million metric tons of plastic waste- not just straws and bags, but food containers, jugs, bottles, packaging, and more_-enter the oceans annually (Lauridsen, 2015). The increased use of disposable masks and personal protective equipment (PPE) related to the COVID-19 pandemic has only exacerbated this problem (Cordova et al., 2021; De-la-Torre \& Aragaw, 2021). 
Deterioration of ocean health also directly affects the 800 million people worldwide who rely on fishing for sustenance (World Wildlife Fund [WWF], 2018).

Agricultural and livestock practices, especially those of large monocultures, also severely deplete soils (Miller, 2013). Soil is the basis for all food production as plants grow in soil and livestock eat plants. But nutrient depletion in soil results from high-density and highly mechanized agriculture and land-use changes. Also at stake is the physical integrity of soil. Poor soil lacking proper amounts of organic materials is more prone to erosion, as became terribly evident in the Dust Bowl of the 1930s (Imhoff \& Badaracco, 2019). Such impacts still lead to the loss of more than $1 \mathrm{~cm}(0.4$ inch) of topsoil annually in the U.S. (National Critical Zone Observatory, 2012). Globally, a third of soils are considered somewhat to severely degraded (Neff, 2014). Ironically, another threat to farmland is that of urbanization. In the U.S., $40 \%$ of agriculture production occurs at the "urban-edge," making it vulnerable to urban expansion ( $80 \%$ of Americans and $50 \%$ of the world's population live in cities, and such urban areas are expanding) (Neff, 2014; U.S. Census Bureau, 2016).

As with water, fertilizers are a significant factor in land degradation. Phosphorous, an important component of fertilizers, is extracted from mines worldwide. Scientists warn of the limited nature of phosphorus and the significant amount of radioactive byproduct (5 tons of this waste for each ton of phosphorous extracted) resulting from phosphorus extraction (Cordell et al., 2009). Food justice becomes relevant again here as, paradoxically, Africa is one of the top producers of the essential phosphorus with which we grow food and is the most food-insecure continent (Syers et al., 2011).

Also at stake is the air we breathe. The processing of food produces air pollution and significant amounts of the GHG emissions that lead to climate change (Poore \& Nemecek, 2018). In fact, a third or more of anthropogenic GHG emissions, much of which comes from meat production, originate from the global food cycle (Foer, 2019; IPCC, 2013; Venkat, 2011). Minority communities and people of color are frontline communities in climate change, as they are disproportionally exposed to the resulting degraded air, water, land, and social systems (Chiapella et al., 2019). Forests, one of the planet's main mechanisms for sequestering GHGs, are being lost at a rate of about 13.5 million hectares (33.4 million acres) worldwide per year, mostly due to agriculture and illegal logging. This rate of loss is, unfortunately, faster than forests can regrow (Silver et al., 2000; WWF, n.d.) (see Figure 3, below). Even considering forests planted to offset said deforestation, net deforestation has increased significantly since the 1990s (Lindquist et al., 2012). Deforestation and forest slash and burn are attributed to $12 \%$ or more of global anthropogenic GHG emissions (World Bank, 2019). Tropical rainforests sequester 228 to 247 gigatons of carbon annually; the fact that we are losing that capacity at such a critical time should immediately cause one to pause and consider the vastness of the impact (WWF, n.d.).

\section{Now, let's talk about one more thing.}

Humans exploit natural, social, and economic systems to produce (cheap) food, and then we waste it. In fact, we waste a whole lot of edible food and all the resources that go into it. Nationally $40 \%$, and globally 30\%, of food produced is wasted annually (Lipinski et al., 2013; Thyberg \& Tonjes, 2016). To put that into perspective, 32.4 million hectares (80 million acres) of farmland in the U.S. are used to produce food that we never eat (ReFED, 2016). More than 10 million pounds of produce never leave farms due to cosmetic imperfections (ReFED, 2016). Thirty-five percent of the freshwater, $31 \%$ of the cropland, and $30 \%$ of the fertilizer in the U.S. are used to produce food that never gets eaten (Johns Hopkins Bloomberg School of Public Health, 2015). An estimated 40\% of seafood caught is considered "bycatch" or unintended fish catch that is thrown back, usually dead—wasted before it even reaches a dock (Feldstein, 2017).

On top of all that, the COVID-19 pandemic led to a spike in wasted food, both preconsumer (due 


\section{Figure 3. Example of a Food Chain Cycle}

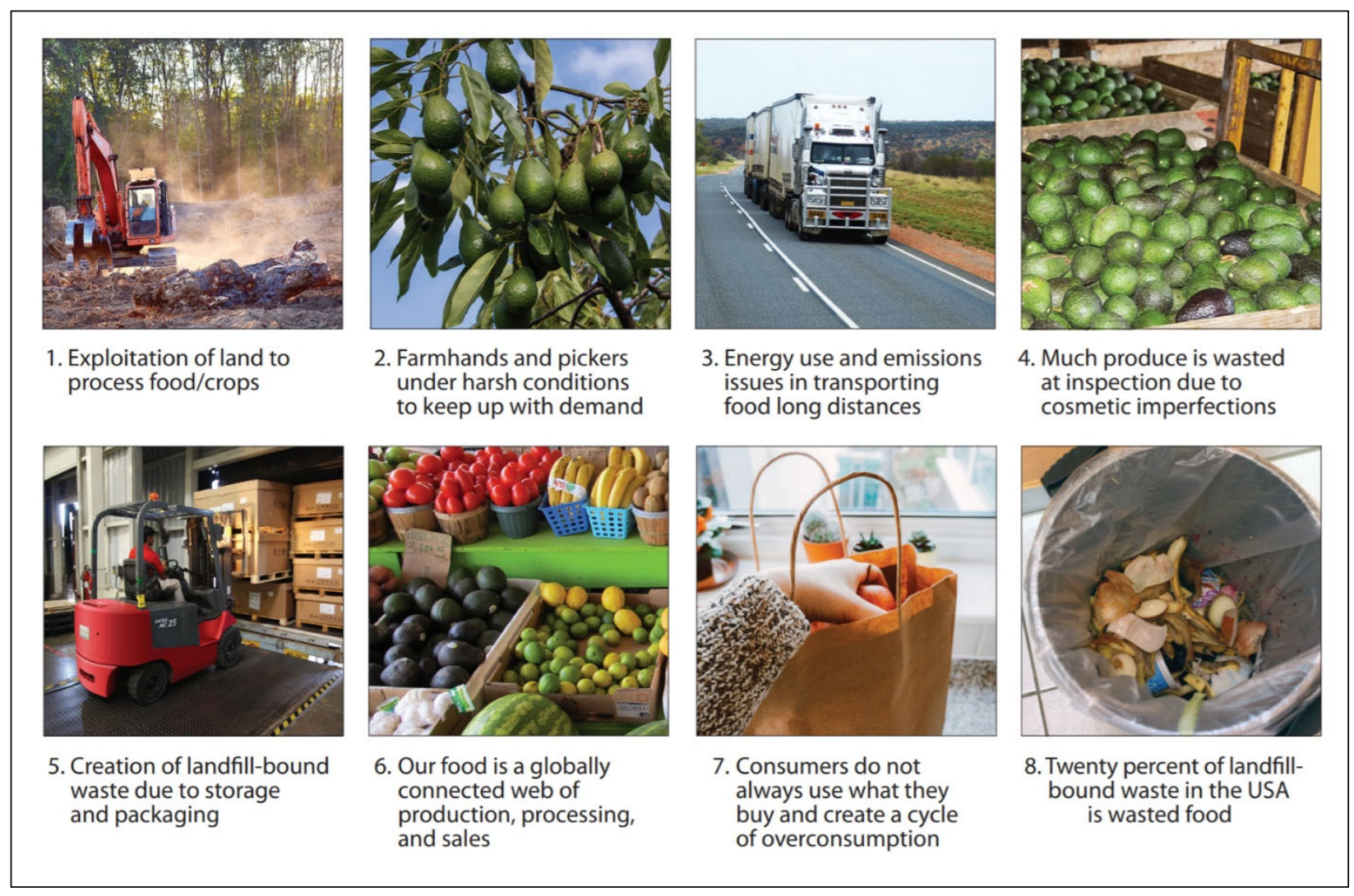

Photos courtesy Pexels and Pixabay. Image created by the author and Patti Davis and her team.

to disruptions in distribution and markets) and postconsumer (as people eat and cook more at home) (Aldaco et al., 2020; Yaffe-Bellany \& Corkery, 2020), although there is hopeful evidence suggesting that improved home skills will eventually decrease household food waste overall (Roe et al., 2020; Seeley, 2020).

The average American wastes more than half a pound of food a day (Thyberg \& Tonjes, 2016). The average American family spends between US $\$ 1,350$ and US\$2,275 per year on food they purchase but never eat (Waters \& McNamara, 2015). Food waste costs the nation an estimated US $\$ 218$ billion and the world US\$2.6 trillion annually (Feldstein, 2017). Twenty percent of landfill-bound waste in the U.S. is wasted food (Schwab, 2012). Once in the landfill, wasted food releases carbon dioxide $\left(\mathrm{CO}_{2}\right)$ along with the even more potent GHGs methane and nitrous oxide (Gunders, 2012). Food waste alone produces an estimated 8\% of anthropogenic GHGs globally (FAO, 2013). The global food system impacts our world in overwhelming ways, yet we waste that impact on the food that is not eaten. As we waste food and resources at an alarming rate, hunger is prevalent, both nationally and internationally (Capone et al., 2014; Weinfield et al., 2014). For this reason, food waste has been deemed "the world's dumbest problem" (Ahmed, 2019).

And it's not just the food that is being wasted. Once again, let's take a bird's eye view, this time over a grocery store. Do you see food? No, besides the produce section, we see only plastic and paper packaging - trash. The U.S. Environmental Protection Agency (EPA) estimates that 29.9\% (80.1 million tons) of landfill-bound waste in the U.S. is packaging (U.S. EPA, n.d.). 


\section{So, what do I do?}

Ok, so we're eating injustice and drowning in trash; how can we redesign the food system? When dealing with a global system, the solution is never simple. But a global system does allow everyone, from policymakers to home gardeners, to help make a difference in their own way. We can start by understanding the complexity of the food system, the impacts it has on social and environmental justice, and the entry points for change. We have only just scratched the surface in this article.

Additionally, the COVID-19 pandemic has made clear what has always been true: our food workers are the core of our livelihoods. They are essential. Our response, though, has been mixed. While local growers, fishers, and communities work to decentralize, find new markets, and distribute much-needed resources, our administration works to deregulate the industry and marginalize many food workers, further entrenching an already-unjust food system (Grillo, 2020; Held, 2020; Jordan, 2020; Mejia et al., 2020; Sethi, 2020; Wozniacka, 2020). In a moment of crisis, there may be a moment for food system change.

Small steps for change include voting with your fork (eating intentionally to reflect your values), planning meals to avoid waste, composting at home, planting a garden, and many other lifestyle changes (Gunders, 2015; Gustafson, 2014). But settling for small lifestyle changes won't make broader change. We also need to vote with our ballots, address systems of inequity nationally and worldwide, and restructure our understanding of and policy around food and consumption (M. Nestle, 2013; Penniman, 2017; Simley, 2017). Consider your niche, your career, your hobbies, and how you might develop the knowledge, skills, and networks to mobilize this change. We must work as a collective to make a real difference (Foer, 2019).

In summary, we are what we eat. Currently, we are eating a food system that is creating imbalances in social, natural, and economic systems. Let's fix our food system.

\section{Acknowledgments}

I would like to thank Patti Davis and her team for soliciting, supporting, and editing the initial draft of this work. Despite the COVID-19 pandemic disrupting the completion of that original publication, Patti and her team were amazing partners. I would also like to acknowledge Amy Benfield for her constant support and help editing the manuscript.

\section{References}

Ahmed, K. (2019). Food waste and copia. University of California Berkeley Edible Education 101. https://www.edibleschoolyard.org/ee101

Aldaco, R., Hoehn, D., Laso, J., Margallo, M., Ruiz-Salmón, J., Cristobal, J., Kahhat, R., Villanueva-Rey, P., Bala, A., Batlle-Bayer, L., Fullana-i-Palmer, P., Irabien, A., \& Vazquez-Rowe, I. (2020). Food waste management during the COVID-19 outbreak: A holistic climate, economic and nutritional approach. Science of The Total Environment, 742 , 140524. https://doi.org/10.1016/j.scitotenv.2020.140524

Bellemare, M. F. (2015). Rising food prices, food price volatility, and social unrest. American Journal of Agricultural Economics, 97(1), 1-21. https://doi.org/10.1093/ajae/aau038

Berners-Lee, M., Kennelly, C., Watson, R., \& Hewitt, C. N. (2018). Current global food production is sufficient to meet human nutritional needs in 2050 provided there is radical societal adaptation. Elementa: Science of the Anthropocene, 6(1), 52. https://doi.org/10.1525/elementa.310

Brown, L. R. (2012). Full planet, empty plates: The new geopolitics of food scarcity (1st Ed.). W. W. Norton \& Company.

Capone, R., El Bilali, H., Philipp, D., Cardone, G., \& Driouech, N. (2014). Food system sustainability and food security: Connecting the dots. Journal of Food Security, 2(1), 13-22. http://pubs.sciepub.com/jfs/2/1/2

Carlisle, L. (2016). Lentil underground: Renegade farmers and the future of food in America. Avery. 
Centers for Disease Control and Prevention (CDC). (n.d.). Overweight \& obesity: Adult obesity facts. https://www.cdc.gov/obesity/data/adult.html

Chiapella, A. M., Grabowski, Z. J., Rozance, M. A., Denton, A. D., Alattar, M. A., \& Granek, E. F. (2019). Toxic chemical governance failure in the United States: Key lessons and paths forward. BioScience, 69(8), 615-630. https://doi.org/10.1093/biosci/biz065

Chislock, M. F., Doster, E., Zitomer, R. A., \& Wilson, A. E. (2013). Eutrophication: Causes, consequences, and controls in aquatic ecosystems. Nature Education Knowledge, 4(4), 10. Retrieved from Wilson Lab website: http://www.wilsonlab.com/publications/2013 NE Chislock et al.pdf

Compensation Force. (2017). 2016 turnover rates by industry. Compensation Force. http://www.compensationforce.com/2017/04/2016-turnover-rates-by-industry.html

Cordell, D., Drangert, J.-O., \& White, S. (2009). The story of phosphorus: Global food security and food for thought. Global Environmental Change, 19(2), 292-305. https://doi.org/10.1016/i.gloenvcha.2008.10.009

Cordova, M. R., Nurhati, I. S., Riani, E., Nurhasanah, \& Iswari, M. Y. (2021). Unprecedented plastic-made personal protective equipment (PPE) debris in river outlets into Jakarta Bay during COVID-19 pandemic. Chemosphere, 268, 129360. https://doi.org/10.1016/i.chemosphere.2020.129360

De-la-Torre, G. E., \& Aragaw, T. A. (2021). What we need to know about PPE associated with the COVID-19 pandemic in the marine environment. Marine Pollution Bulletin, 163, 111879. https://doi.org/10.1016/j.marpolbul.2020.111879

Derraik, J. G. B. (2002). The pollution of the marine environment by plastic debris: A review. Marine Pollution Bulletin, 44(9), 842-852. https://doi.org/10.1016/s0025-326x(02)00220-5

Edelson, M., Monani, S., \& Platt, R. V. (2018). Migrant farmworkers' perceptions of pesticide risk exposure in Adams County, Pennsylvania: A cultural risk assessment. Journal of Agriculture, Food Systems, and Community Development, 8(1), 71-96. https://doi.org/10.5304/jafscd.2018.081.005

Edible Schoolyard Project, The. (2019, February 13). What the new farm bill means and why it matters, Nina Ichikawa, Shanti Prasad, Christina Badaracco [Video]. YouTube. https://youtu.be/C1f5HrTsZg8

Feeding America. (n.d.). Facts about poverty and bunger in America. http://www.feedingamerica.org/hunger-in-america/impact-of-hunger/hunger-and-poverty/

Feldstein, S. (2017). Wasting biodiversity: Why food waste needs to be a conservation priority. Biodiversity, 18(2-3), 7577. https://doi.org/10.1080/14888386.2017.1351891

Fisher, A. (2017). Big bunger: The unboly alliance between corporate America and anti-bunger groups. The MIT Press.

Foer, J. S. (2019). We are the weather: Saving the planet begins at breakfast. Farrar, Straus and Giroux.

Food and Agriculture Organization of the United Nations [FAO]. (2013). Food wastage footprint: Impacts on natural resources. http://www.fao.org/nr/sustainability/food-loss-and-waste/en/

FAO. (2017). Water for sustainable food and agriculture. http://www.fao.org/3/a-i7959e.pdf

Food Chain Workers Alliance \& Solidarity Research Cooperative. (2016). No piece of the pie: U.S. food workers in 2016. http://foodchainworkers.org/wp-content/uploads/2011/05/FCWA NoPieceOfThePie_P.pdf

Gaddis, J. E., Coplen, A. K., Clark-Barol, M., Martin, A., Barrett, C. K., \& Lubowicki, L. (2020). Incorporating local foods into low-income families' home-cooking practices: The critical role of sustained economic subsidies. Journal of Agriculture, Food Systems, and Community Development, 10(1), 117-132. https://doi.org/10.5304/jafscd.2020.101.019

Gowen, A. (2019, November 9). 'I'm gonna lose everything.' The Washington Post. https://www.washingtonpost.com/nation/2019/11/09/im-gonna-lose-everything/

Grillo, C. (2020, March 30). Food security in the time of Covid: It's not charity, it's justice. Johns Hopkins Center for a Livable Future. https://clf.jhsph.edu/stories/food-security-time-covid-its-not-charity-its-justice

Gunders, D. (2012). Wasted: How America is losing up to 40 Percent of its food from farm to fork to landfill (NRDC Issue Paper No. 12-06-B). Retrieved from Natural Resources Defense Council website: https://www.nrdc.org/sites/default/files/wasted-food-IP.pdf

Gunders, D. (2015). Waste-free kitchen handbook: A guide to eating well and saving money by wasting less food (1 ${ }^{\text {st }}$ Ed.). Chronicle. Gustafson, E. (2014). We the eaters: If we change dinner, we can change the world. Rodale. 
Hake, M., Dewey, A., Engelhard, E., Strayer, M., Harper, T., Summerfelt, T., Malone-Smolla, C., Maebry, T., \& Gundersen, C. (2020). The impact of the coronavirus on food insecurity in 2020. Feeding America. https://www.feedingamerica.org/sites/default/files/2020-10/Brief Local\%20Impact 10.2020 0.pdf

Held, L. (2020, May 19). As COVID-19 disrupts the industrial meat system, independent processors have a moment to shine. Civil Eats. https:// civileats.com/2020/05/19/as-covid-19-disrupts-the-industrial-meat-system-independentprocessors-have-a-moment-to-shine/

Henne, B. (2012, September 20). How far did your food travel to get to you? Michigan State University Extension. https://www.canr.msu.edu/news/how far did your food travel to get to you

Hernandez, T., \& Gabbard, S. (2018). Findings from the National Agricultural Workers Survey (NAWS) 2015-2016: A demographic and employment profile of United States farmworkers (Research Report No. 13). Retrieved from U.S. Department of Labor website: https://www.dol.gov/agencies/eta/national-agricultural-workers-survey/research

Higgins, J. (2019, April 12). U.S agriculture census shows fewer farms, bigger operations. United Press International. https://www.upi.com/Top_News/US/2019/04/12/US-agriculture-census-shows-fewer-farms-biggeroperations/6981555093219/

Hoekstra, A. Y. (2008). The water footprint of food. In J. Förare (Ed.), Water for food (pp. 49-61). The Swedish Research Council for Environment. https://research.utwente.nl/en/publications/the-water-footprint-of-food

Imhoff, D., \& Badaracco, C. (2019). The farm bill: A citizen's guide ( $3^{\text {rd }} \mathrm{Ed}$.). Island Press.

Intergovernmental Panel on Climate Change [IPCC]. (2013). Food security. In IPPC, Climate change 2013: The physical science basis. Contribution of Working Group I to the Fifth Assessment Report of the Intergovernmental Panel on Climate Change (pp. 5-1 to 5-200). Cambridge University Press. https://www.ipcc.ch/site/assets/uploads/2019/08/2f.-Chapter-5_FINAL.pdf

Jayaraman, S. (2016). Forked: A new standard for American dining (1 ${ }^{\text {st }}$ ed.). Oxford University Press.

Johns Hopkins Bloomberg School of Public Health. (2015, June 11). Americans may be wasting more food than they think [Press release]. http://www.jhsph.edu/news/news-releases/2015/americans-may-be-wasting-more-food-than-they-think.html

Jordan, M. (2020, April 2). Farmworkers, mostly undocumented, become 'essential' during pandemic. The New York Times.

https://www.nytimes.com/2020/04/02/us/coronavirus-undocumented-immigrant-farmworkers-agriculture.html

Klein, E., \& Locke, S. (2014, June 9). 40 maps that explain food in America. Vox. https://www.vox.com/a/explain-food-america

Lal, R. (2020). Home gardening and urban agriculture for advancing food and nutritional security in response to the COVID-19 pandemic. Food Security, 12(4), 871-876. https://doi.org/10.1007/s12571-020-01058-3

Lauridsen, H. (2015, June 16). When plastic outnumbers plankton: Insights into the Great Pacific garbage patch. U.S. Mission to ASEAN. https://asean.usmission.gov/innovasean_20150615/

Li, W. C., Tse, H. F., \& Fok, L. (2016). Plastic waste in the marine environment: A review of sources, occurrence and effects. Science of The Total Environment, 566-567, 333-349. https://doi.org/10.1016/j.scitotenv.2016.05.084

Lin, X., Ruess, P. J., Marston, L., \& Konar, M. (2019). Food flows between counties in the United States. Environmental Research Letters, 14(8), 084011. https://doi.org/10.1088/1748-9326/ab29ae

Lindquist, E. J., D’Annunzio, R., Gerrand, A., MacDicken, K., Achard, F., Beuchle, R., ... Stibig, H.-J. (2012). Global forest land-use change 1990-2005 (FAO Forestry Paper No. 169). FAO. http://www.fao.org/3/i3110e/i3110e.pdf

Linthicum, K. (2019, November 21). Inside the bloody cartel war for Mexico's multibillion-dollar avocado industry. Los Angeles Times. https://www.latimes.com/world-nation/story/2019-11-20/mexico-cartel-violence-avocados

Lipinski, B., Hanson, C., Waite, R., \& Searchinger, T. (2013). Reducing food loss and waste (Creating a Sustainable Food Future Working Paper No. 2). World Resources Institute. https://www.wri.org/research/reducing-food-loss-and-waste

MacDonald, J. M. (2019, February 15). Mergers in seeds and agricultural chemicals: What happened? USDA ERS. https://www.ers.usda.gov/amber-waves/2019/february/mergers-in-seeds-and-agricultural-chemicals-whathappened/ 
Margulis, M. E., McKeon, N., \& Borras, S. M. (2013). Land grabbing and global governance: Critical perspectives. Globalizations, 10(1), 1-23. https://doi.org/10.1080/14747731.2013.764151

Marquis, S. L. (2017). I am not a tractor: How Florida farmworkers took on the fast food giants and won. Cornell University Press.

Mbow, C., Rosenzweig, C., Barioni, L. G., Benton, T. G., Herrero, M., Krishnapillai, M., Liwenga, E., Pradhan, P., Rivera-Ferre, M., Sapkota, T., Tubiello, F., \& Xu, Y. (2019). IPCC report chapter 5: Food security-Special report on climate change and land [IPCC SRCCL]. Intergovernmental Panel on Climate Change (IPCC). https://www.ipcc.ch/site/assets/uploads/2019/08/2f.-Chapter-5 FINAL.pdf

McCoy, T. (2019, August 22). The Amazon is burning. The $W$ ashington Post. https://www.washingtonpost.com/graphics/2019/world/amp-stories/amazon-fires-causes-rainforest-climatechange/

Mejia, A., Bhattacharya, M., Nigon-Crowley, A., Kirkpatrick, K., \& Katoch, C. (2020). Community gardening during times of crisis. Journal of Agriculture, Food Systems, and Community Development, 10(1), 13-19. https://doi.org/10.5304/jafscd.2020.101.006

Milken Institute. (2018, October 30). Economic impact of excess weight now exceeds $\$ 1.7$ trillion. ScienceDaily. https://www.sciencedaily.com/releases/2018/10/181030163458.htm

Miller, D. (2013). Farmacology: Total health from the ground up. William Morrow.

National Critical Zone Observatory. (n.d.). The critical zone. https://criticalzone.org/national/research/the-critical-zone-1national/

National Oceanic and Atmospheric Administration [NOAA]. (2019). What is eutrophication? NOAA National Ocean Service. https://oceanservice.noaa.gov/facts/eutrophication.html

Neff, R. (2014). Introduction to the US food system: Public health, environment, and equity. Wiley.

Nestle, D. M., Bittman, M., \& Baer, N. (2015). Soda politics: Taking on big soda (1 ${ }^{\text {st }}$ Ed.). Oxford University Press.

Nestle, M. (2013). Eat drink vote: An illustrated guide to food politics (1 ${ }^{\text {st }}$ Ed.). Rodale Books.

Newkirk II, V. R. (2019). The great land robbery. The Atlantic. https://www.theatlantic.com/magazine/archive/2019/09/this-land-was-our-land/594742/

Niewolny, K. L., \& Lillard, P. T. (2010). Expanding the boundaries of beginning farmer training and program development: A review of contemporary initiatives to cultivate a new generation of American farmers. Journal of Agriculture, Food Systems, and Community Development, 1(1), 65-88. https://doi.org/10.5304/jafscd.2010.011.010

Northridge, M. E., Stover, G. N., Rosenthal, J. E., \& Sherard, D. (2003). Environmental equity and health: Understanding complexity and moving forward. American Journal of Public Health, 93(2), 209-214. https://doi.org/10.2105/AJPH.93.2.209

Pappas, S. (2020, September 24). COVID-19 fallout hits farmers. American Psychological Association. https://www.apa.org/topics/covid-19/farming-communities-stress

Patel, R. (2012). Stuffed and starved: The hidden battle for the world food system - Revised and updated. Melville House.

Patel, R. \& Moore, J. W. (2017). A history of the world in seven cheap things (1 ${ }^{\text {st }}$ ed.). University of California Press.

Penniman, L. (2017, April 27). 4 not-so-easy ways to dismantle racism in the food system. Yes! Magazine. https://www.yesmagazine.org/democracy/2017/04/27/4-not-so-easy-ways-to-dismantle-racism-in-the-food-system

Penniman, L. (2018). Farming while Black: Soul Fire Farm's practical guide to liberation on the land. Chelsea Green Publishing.

Perea, J. F. (2010). The echoes of slavery: Recognizing the racist origins of the agricultural and domestic worker exclusion from the National Labor Relations Act. Social Science Research Network. https://doi.org/10.2139/ssrn.1646496

Perez, I. (2013, March 4). Climate change and rising food prices heightened Arab Spring. Scientific American. https://www.scientificamerican.com/article/climate-change-and-rising-food-prices-heightened-arab-spring/

Pollan, M. (2008). In defense of food: An eater's manifesto (1 ${ }^{\text {st }}$ Ed.). Penguin Books.

Pollan, M. (2015). Introduction [YouTube video]. UC Berkeley Edible Education 101. https://www.youtube.com/watch?v=Kwa3ppwvn-k

Poore, J., \& Nemecek, T. (2018). Reducing food's environmental impacts through producers and consumers. Science, 360(6392), 987-992. https://doi.org/10.1126/science.aaq0216 
Poska, J. (2019, May 29). Where the 2020 presidential candidates stand on food and farming. Civil Eats. https://civileats.com/2019/05/29/where-the-2020-presidential-candidates-stand-on-food-and-farming/

Raff, Z., \& Meyer, A. (2019). CAFOs and surface water quality: Evidence from the proliferation of large farms in Wisconsin (SSRN Scholarly Paper ID 3379678). Social Science Research Network. https://doi.org/10.2139/ssrn.3379678

ReFED. (2016). A roadmap to reduce U.S. food waste by 20 percent. Rethink Food Waste: Through Economics and Data (ReFED). https://refed.com/downloads/Executive-Summary.pdf

Rodman-Alvarez, S., \& Colasanti, K. (2019, May 6). Measuring racial equity in the food system: Established and suggested metrics. Michigan State University Center for Regional Food Systems. https://www.canr.msu.edu/resources/measuring-racial-equity-in-the-food-system

Roe, B. E., Bender, K., \& Qi, D. (2020). The impact of COVID-19 on consumer food waste. Applied Economic Perspectives and Policy, 43(1), 401-411. https://doi.org/10.1002/aepp.13079

Rosmann, M. (2017, July 21/Updated November 15). Farmer suicide continues to be unresolved problem [Online column]. Farm and Ranch Guide. https://www.agupdate.com/farmandranchguide/opinion/columnists/farm_and_ranch_life/farmer-suicidecontinues-to-be-unresolved-problem/article 843c55dc-ca22-11e7-a811-33c48d52e1dd.html

Rulli, M. C., Saviori, A., \& D’Odorico, P. (2013). Global land and water grabbing. Proceedings of the National Academy of Sciences, 110(3), 892-897. https://doi.org/10.1073/pnas.1213163110

Schapiro, M. (2018). Seeds of resistance: The fight to save our food supply. Simon \& Schuster.

Schwab, J. (2012, August 30). US EPA sustainable food management: Feed people not landfills [U.S. EPA Region 2 Greening the Food Services Sector webinar]. https://www.youtube.com/watch?v=NQG-0rfC7KE

Seeley, E. (2020, September 28). After a sharp increase, the rate of food waste may be slowing. Food Tank. https://foodtank.com/news/2020/09/after-a-sharp-increase-the-rate-of-food-waste-may-be-slowing/

Sethi, S. (2020, June 3). How fostering empathy for the people who feed us could change our food system. Civil Eats. https://civileats.com/2020/06/03/how-fostering-empathy-for-the-people-who-feed-us-could-change-our-foodsystem/

Sewell, S. (2019, April 29). There were nearly a million black farmers in 1920. Why have they disappeared? The Guardian. https://www.theguardian.com/environment/2019/apr/29/why-have-americas-black-farmers-disappeared

Silver, W. L., Ostertag, R., \& Lugo, A. E. (2000). The potential for carbon sequestration through reforestation of abandoned tropical agricultural and pasture lands. Restoration Ecology, 8(4), 394-407. https://doi.org/10.1046/j.1526-100x.2000.80054.x

Simley, S. (2017, October 4). How food can be a platform for activism. Longreads. https://longreads.com/2017/10/04/how-food-can-be-a-platform-for-activism/

Singh, K. D. (2020, September 8). 'The lockdown killed my father': Farmer suicides add to India's virus misery. The New York Times. https://www.nytimes.com/2020/09/08/world/asia/india-coronavirus-farmer-suicides-lockdown.html

Springmann, M., Clark, M., Mason-D’Croz, D., Wiebe, K., Bodirsky, B. L., Lassaletta, L., de Vries, W., Vermeulen, S. J., Herrero, M., Carlson, K. M., Jonell, M., Troell, M., DeClerck, F., Gordon, L. J., Zurayk, R., Scarborough, P., Rayner, M., Loken, B., Fanzo, J., ... Willett, W. (2018). Options for keeping the food system within environmental limits. Nature, 562(7728), 519-525. https://doi.org/10.1038/s41586-018-0594-0

Syers, K., Bekunda, M., Cordell, D., Corman, J., Johnston, J., Rosemarin, A., Salcedo, I., \& Lougheed, T. (2011). Phosphorus and food production. UNEP Year Book 2011. https://fsc.unihohenheim.de/fileadmin/einrichtungen/fsc/Intranet/Intranet MOSA/MOSA Updated/5 UNEP 2011.pdf

Thyberg, K. L., \& Tonjes, D. J. (2016). Drivers of food waste and their implications for sustainable policy development. Resources, Conservation and Recycling, 106, 110-123. https://doi.org/10.1016/j.resconrec.2015.11.016

Townsend, R., Benfica, R., Prasann, A., \& Lee, M. (2017). Future of food: Shaping the food system to deliver jobs (Working Paper No. 114394). The World Bank. http://documents.worldbank.org/curated/en/406511492528621198/Future-offood-shaping-the-food-system-to-deliver-jobs

United Nations [UN]. (2015). United Nations Millennium Development Goals. http://www.un.org/millenniumgoals/news.shtml 
U.S. Census Bureau. (2016, December 8). New census data show differences between urban and rural populations. https://www.census.gov/newsroom/press-releases/2016/cb16-210.html

U.S. Environmental Protection Agency [EPA]. (n.d.). Containers and packaging: Product-specific data [Data and Tools]. Retrieved December 2020 from https://www.epa.gov/facts-and-figures-about-materials-waste-andrecycling/containers-and-packaging-product-specific-data

U.S. Department of Agriculture [USDA]. (2004). National program 206: Manure and byproduct utilization action plan. https://www.ars.usda.gov/ARSUserFiles/np206/206ActionPlan2004/NP206ActionPlanOctober2004Revisedwosy names.pdf

USDA. (2014). U.S. forest resource facts and historical trends. https://www.srs.fs.usda.gov/products/marketing/cards/fs1035.pdf

USDA. (2017). Food dollar application. https://data.ers.usda.gov/reports.aspx?ID=17885\&reportPath=/FoodDollar/Nominal

USDA Economic Research Service [USDA ERS]. (2020). Food security and nutrition assistance. https://www.ers.usda.gov/data-products/ag-and-food-statistics-charting-the-essentials/food-security-andnutrition-assistance/

Venkat, K. (2011). The climate change and economic impacts of food waste in the United States. International Journal on Food System Dynamics, 2(4), 431-446. https://doi.org/10.18461/ijfsd.v2i4.247

Water Footprint Calculator. (2020). Food's big water footprint. https://www.watercalculator.org/water-use/foods-big-water-footprint/

Waters, A., \& McNamara, C. (2015). Teaching slow food values in a fast food world [YouTube video]. UC Berkeley Edible Education 101. https://www.youtube.com/watch?v=TfEjp-jZYh4

Waters, H., \& Graf, M. (2018). America's obesity crisis: The health and economic costs of excess weight. Retrieved from Milken Institute website: https://milkeninstitute.org/sites/default/files/reports-pdf/Mi-Americas-Obesity-Crisis-WEB.pdf

Weinfield, N. S, Mills, G., Borger, C., Gearing, M., Macaluso, T., Montaquila, J., \& Zedlewski, S. (2014). Hunger in America 2014: National report. Retrieved from Feeding America website: https://www.feedingamerica.org/sites/default/files/2020-02/hunger-in-america-2014-full-report.pdf

Weingarten, D. (2018, December 11). Why are America's farmers killing themselves? The Guardian. https://www.theguardian.com/us-news/2017/dec/06/why-are-americas-farmers-killing-themselves-in-recordnumbers

World Bank. (2019). Forests and terrestrial ecosystems. https://www.worldbank.org/en/topic/forests

World Health Organization [WHO]. (2019, June 18). 1 in 3 people globally do not have access to safe drinking water. WHO/UNICEF Joint Monitoring Program. https://www.who.int/news-room/detail/18-06-2019-1-in-3-peopleglobally-do-not-have-access-to-safe-drinking-water-unicef-who

World Wildlife Fund [WWF]. (n.d.). Deforestation and forest degradation: Overview. https://www.worldwildlife.org/threats/deforestation-and-forest-degradation

WWF. (2018, October 16). World Food Day: Fish gone, people gone. https://wwf.panda.org/?336754/World-Food-Day-fishgone-people-gone

Wozniacka, G. (2020, April 17). Poor conditions at meatpacking plants have long put workers at risk. The pandemic makes it much worse. Civil Eats. https://civileats.com/2020/04/17/poor-conditions-at-meatpacking-plants-havelong-put-workers-at-risk-the-pandemic-makes-it-much-worse/

Yaffe-Bellany, D., \& Corkery, M. (2020, April 11). Dumped milk, smashed eggs, plowed vegetables: Food waste of the pandemic. The New York Times. https://www.nytimes.com/2020/04/11/business/coronavirus-destroyingfood.html

Yeung, B. (2018). In a day's work: The fight to end sexual violence against America's most vulnerable workers. The New Press. 